\title{
DEVELOPMENT OF SERBIAN CARTOGRAPHY FROM THE END OF XVIII TO THE BEGINNING OF THE XX CENTURY
}

\author{
Mirko Grčić ${ }^{* 1}$ \\ * University of Belgrade - Faculty of Geography, Belgrade
}

\begin{abstract}
This paper represents summary of development of geographical and cartographical knowledge of Serbian authors about Serbia and Balkan. Important maps in the Serbian language are presented with a brief overview of their content, context and methodology. The main directions, stages of development and the most important cartographers and cartographic works in the Serbian language from the end of the XVII century to the creation of the Yugoslav state in the first quarter of the $\mathrm{XX}$ century are discussed. During this period, great historical and geopolitical changes took place in the Balkan Peninsula, such as revolutions, uprisings and wars, awakening the national consciousness of the Balkan peoples and the creation of nation-states. The development of Serbian cartography and geography in this period ranged from national romanticism, through descriptive and inventorying of geographical material, to explicit and applied scientific geography and cartography, which began with the establishment of two institutions at the end of the $19^{\text {th }}$ century - the Geographical Section of the Serbian Army General Staff (today the Military Geographical Institute) and the Geographic institutes at the Big School (today's Faculty of Geography, University of Belgrade). The author traces the development of cartography through the evolution of content and the interpretation of the context of maps.
\end{abstract}

Key words: old maps of Serbia, old maps of the Balkans, historical cartography of Serbia, historical geography of Serbia, history of cartography.

1 Corresponding author: M. Grčić, University of Belgrade-Faculty of Geography, Belgrade; e-mail: mirko@gef.bg.ac.rs 


\section{Introduction}

At the end of the $18^{\text {th }}$ and in the $19^{\text {th }}$ century, the development of Serbian geography went through several phases, which found their resonance in cartography as well. The first phase is the awakening of interest in the geography of Serbian countries, regarding the national revival and the return of Serbia to the European historical scene. In the newly liberated small Principality of Serbia, first printed translations of foreign authors appeared and geography was introduced into the curriculum of the Great School (1808). The second stage is geographical romanticism. More discerning educated people begin to collect geographic and ethnographic material, inventory geographic phenomena and processes and draw maps. The third is the descriptive phase, when educated people in civilian or military service begin to engage in field research and descriptions of particular landscapes. The fourth is the explicative phase, which begins with the establishment of the Geographical Institute (1893) in Belgrade and the work of professional geographers who deal with scientific explanations of the genesis and evolution of geographical phenomena and processes. Comparatively begins the fifth phase in which applied geography is emerging, finding application in various spheres of social practice in the $20^{\text {th }}$ century.

An overview of maps of Serbia in the first half of the $19^{\text {th }}$ century was given by Felix Kanitz in the paper "Beitrage zur Kartographie des Fustenthums Serben", published in the Journal of the Academy of Sciences in Vienna in 1863. Then, Petar Matković published the paper "Најновија картографија о југословјенских земљах" (The Latest Cartography on Yugoslav Countries) in magazine "Književnik" 1/1866. One of the first Serbian works was "Грађа за картографију и за географију Србије" (Material for Cartography and Geography of Serbia), published by Anta Aleksić in "Годишњица" of Nikola Čupić in 1883. Milivoje Nikolajević then published a paper entitled "Новија географско-картографска књижевност Балканског полуострва" (Recent Geographic-Cartographic Literature in the Balkan Peninsula) in 1890. Jovan Cvijić launched the first referral publication “Прегледлитературе о Балканском полуострву" (A Review of the Literature on the Balkan Peninsula) in the journal "Delo" in 1894, and then as a stand-alone journal (Стефановић, 2003).

In previous researches, much attention has been paid to the old geographical maps of European cartographers. Stojan Novaković, Jovan Cvijić, Nikola Radojčić, Ilija Sindik and others began studying the old maps of Serbia and Serbian countries. Sindik produced two volumes of the atlas Cmape kapme југословенских земаља (Atlas of the Old Map of the Yugoslav Countries), without interpreters, published by the Serbian Geographical Society $(1931,1932)$. The Institute of History published in redaction of G. Škrivanić two volumes of atlases of Monumenta cartographica Jugoslavica I (1975) and II (1979). More valuable scien- 
tific papers on ancient maps have been published on the pages of the Historical Journal and the Bulletin of the Serbian Geographical Society. The National Library of Serbia published a reprint of some maps and atlas of "Југословенске земье на старим географским картама: XVI, XVII, XVIII. век" (Yugoslav countries on old geographical maps: $16^{\text {th }}, 17^{\text {th }}, 18^{\text {th }}$ Centuries) (Живковић, 1990). The SANU Gallery has published a catalog of the exhibition: Serbia and neighboring countries on old geographic maps (Шкаламера, 1991). Publishing house "Svetigora", published Amлас Старе Србије - Европске карте Косова и Метохије (the Atlas of Old Serbia - European maps of Kosovo and Metohija) (Вемић и Стругар, 2007). Old maps of Serbian cartographers, in the Serbian language, were a rare preoccupation of researchers. Only several papers of a overview character deserve attention (Петровић, 1980, 1997; Стефановић, 2003; Грчић, 2005; Вемић, 2007; Бакрач, Радојчић, Секуловић, 2016).

\section{A theoretical and methodological approach to the study of old maps}

Mapping of the Serbian people and the Serbian lands in the $19^{\text {th }}$ and the first half of the $20^{\text {th }}$ century was a complex field of ideological and scientific work on which different geopolitical conceptions and ideologies were confronted, permeated and tested in action. First maps of Serbia in the Serbian language were printed at the beginning of the $19^{\text {th }}$ century in Vienna and were intended for military purposes, with the aim of benefiting the Serbian revolution and creating the nucleus of Serbian statehood. Subsequently, in the second half of the $19^{\text {th }}$ century, Serbian military cartography gained a great boost, but geopolitical maps also emerged, with an emphasis on the ethnic and religious affiliation of the still-not liberated Serbian countries and the issues of the borders of the newly formed states. At the same time, regarding the development of education, the first Serbian general geographical school maps appears. With regard to landscaping and the use of natural resources, the first engineering maps in the Serbian language also appear.

With regard to the scientific study of old maps, J. B. Harley established two methodological approaches (Harley, 1990). The first is the traditional way of interpreting the map as a reflection of the real world where the focus of the map researcher is the map as text (construction and graphic language of the map). Toponomastic research and analyzes of historical maps can be useful for reconstructing of ethnic history and directions of migratory flows in past epochs as well as in regional researches (Ћирковић, 1991).

The second is a postmodern approach, where the aim is to decode the graphic language in an appropriate temporal and spatial context, taking into account historical facts, cartographic principles, and other maps of a given 
space and time (Harley J. B., 1990). Second, contextual approach is applied in this paper in order to show the influence of geopolitical, cultural and subjective motives on the production, types and quality of Serbian maps produced by Serbian cartographers. Such approach sheds new light on the goals, substance and significance of some maps, thus propelling scientific thought forward. From the point of view of the methodology of making and the accuracy of the map as a text, all the maps from this period can be found many objections. However, here we are primarily interested in the context, aim and purpose of the maps. Errors in the location of objects, toponyms and the like are obvious. However, other sources, such as yearbooks, ethnographic material, geographical nomenclature of that time, and archeology should be explored in deciphering the context (Grčić, M., Grčić, Lj., Sibinović, M. 2018). The context can be decoded on the basis of historical-geographical, socio-geographical, anthropo-geographical, cultural-geographical and other facts, cartographic principles and comparisons, as well as personal data of the cartographers, purchaser and users for whom the maps were intended. This requires a deeper interdisciplinary scientific approach and a broader scientific erudition. In this sense, this paper aims not only to show the main directions and stages of cartographic production in Serbia in the observed period, but to scientifically explain some important historical factors, circumstances and subjective motives that influenced the production, content and purpose of certain maps. This can better illuminate the essence of some maps and delve deeper into their meaning in the time in which they were made, which is often overlooked and labeled incorrectly.

The question is, are geographical maps obsolete? Over time, geographical maps fall into the category of historical maps. We can say that over time they do not age, they retain their cognitive interest for two reasons - as illustrations and as documents of their time. The value of the map as a historical source is related to its territory. Old maps, like old scriptures and monuments, are the "remedy against forgetfulness". Not only that, geographical space has always been a complex field where historical processes took place and left their mark on it. Geography and history are interconnected and intertwined so that they cannot engage in scientific explanations without each other. Zaharije Stefanović Orfelin in foreword of his book „Историје о животу и славним делима Петра првог" (History of the life and famous forks of Peter the First) (1774), says that "reading history cannot be as clear and as comprehensible as when the reader knows geography and has a geographical map at hand". 


\section{The first maps and geographical writings in the Serbian language in the $18^{\text {th }}$ century}

At the time of Turkish rule, there were no conditions for exact instrumental measurements, field research and mapping in Serbia. For these reasons, Serbian scientific geography and cartography were too late for European achievements. The awakening of national consciousness among the Serbs encouraged the need to study the geographical and ethnographic features of the wider areas and stillnot liberated Serbian countries.

Zaharije Stefanović Orfelin (1726-1785), was a Serbian enlightener and writer, cartoonist, calligrapher, cartographer and engraver. He was born in a Serb family in Vukovar and died in Novi Sad. His first surname was Stefanović, and later he adopted the nickname Orfelin (Orpheus and Linus - ancient Greek singers; French orphelin = orphan). He began publishing the first Serbianlanguage magazine "Slaveno-serbski magazin" in Venice in 1768. "Today we can say that Serbian cartography begins with Orfelin"Радошевић, 1976). Zaharije Orfelin is considered the most important cartographer and founder of Serbian cartography (Живковић, 2012). Orfelin's most comprehensive work "Историја о животу и славним делима Петра Првог" (The History of the Life and Famous Works of Peter the First), published in Venice in 1772, and the illustrated edition in Petrograd in 1774 , is the greatest work of $18^{\text {th }}$ century Serbian literature. The work is illustrated with 13 cartographic works, including 8 maps and 5 plans. The first part of the book contains 11 cartographic contributions and the second part contains two (Һурчић, 1972). Orfelin's maps were an integral part of the text and served to better understand the contents of the book. In foreword, he says, "Reading history cannot be as clear and as comprehensible as when the reader knows the geography and has a geographical map at hand". Orfelin drew maps very precisely, meticulously, with a sense of arrangement of content elements and of aesthetics. His maps contain mathematical-geographical elements (scale, projection, composition, frame and orientation) and general geographical elements (relief, hydrography, settlements, forest areas, borders, fortifications and sites of important battles). Only, there were no roads. The relief is represented by the use of individual hums in the form of shaded molehills; rivers are marked with one or two lines and forests - a group of trees with shadows. The inhabited places are shown with a drawing of the tower with the building (Радошевић, 1976). The geographical names are written in civil Cyrillic, as is the text in the book. On the General map of the All-Russian Empire, the first in a row, in the left corner, Orfelin signed on as a member of the Vienna Academy of Arts: „Захарија Орфелин обојих Ц. К. Вијен. Акад. Худож. Члан; рјезал у Карловцје 1774". The fifth map in the series, entitled "Pannonia, Mysia, Dacia, Illyricum" (Панония, Мизия, Дация, Иллирикъ) was also published in Rajić's 
"History", 1794. In 1775, on copper-cut of the Krušedol monastery, Orfelin also drew the plan of monastery estate (Грунт манастира Крушедол). "This plan, as far as is known for the time being, could be characterized as the first Serbian original cartographic work, since the rest of Orfelin's maps were made according to foreign templates" (Шкаламера, 1991). However, Orfelin did not simply sketch the maps, but tried to update them with new data. On the map of Little Tataria he depicted "New Serbia", which represented the settlements of Serbs who immigrated to Russia on the shores of the Dnieper River in the mideighteenth century (1752-53). Unfortunately, Orfelin did not compile a map of Serbia. The first geographic information on Serbian lands in the $18^{\text {th }}$ century can be found in the works of church dignitaries Vasilije Brkić, Jovan Rajić and Stefan Stratimirović.

Vasilije Brkić, Serbian patriarch of the Patriarchate of Peć, was born in Sremski Karlovci and died in Petrograd in 1772. He gave his view of all Serbian provinces in the paper „Опис турских области и у юима хришћанских народа, a нарочито народа српскога" (Description of the Turkish Areas and in them the Christian Peoples, and especially the Serbian Peoples), compiled in 1771, which was published in the journal "Spomenik" No. 10, Serbian Royal Academy in Belgrade (1891). Based on the "long line of questions" he received from Russian Admiral Count Alexei Orlov in Livorno (1770), he produced in 1771 his "landmark study" on Serbian and Orthodox provinces in European Turkey. This was probably the same questionnaire Lomonosov wrote in 1761 as a guide to the study of Russia. It covered about 30 geographical phenomena. "From the text of the answers to this survey one could get an idea of the geographical feature of the studied territory" (Ристић, 1993). Patriarch Brkić, as a nun, traveled extensively across Serbian lands and the Balkan Peninsula, so his elaboration was "the first extensive geography of Serbian countries; Serbia's geography is quite general, but not without interest. Unfortunately, his "publication was printed after a full hundred and twenty years" (Радојчић, 1927; Ракићевић, 1995).

Jovan Rajić (Sremski Karlovci, 1726 - Kovilj, 1801), Archimandrite of the Kovilj Monastery, a well-known Serbian theologian and historian, published a work entitled "История разныхъ словенских народовъ, наипаче Болгаръ, Хорватовъ и Сербовъ" (four volumes in 11 books, completed in 1768 but because of censorship only 1794 were printed) ((Денић, 1996). According to Radojčić, "of the printed books, there were the most notices of Serbian lands in Rajićs History". Thus, it "became not only a historical but also a geographical magazine, though Rajić knew very little about the geography of the Serbian lands" (Радојчић, 1924). The book includes two maps: a Map of Scythia, the ancient homeland of Slavs and a Map of Pannonia and Illyria. He acquired the maps from the Atlas of Jovan Tomka Saski. "The maps were cut by Zaharija Orfelin" (Јовановић, 1958). Maps were created in cooperation of Saski, Zaharije Orfelin and Rajić. These 
maps influenced the formation of the first ideas by Serbs about Slovenian and South Slavic countries (Петровић, 1997). Rajić was the first to show the directions and pace of migration of Serbs after the loss of the state. Rajić is considered the originator of Serbian historical geography. "Through his work, he brought to the light of science the toponymy of the Serbian lands, especially in the Middle Ages. He was the first to introduce Europe with Serbian migrations. Rajić would certainly have been more successful in this effort had his knowledge of the relief and geography of the Balkans been more substantial". An analysis of the content of his "History" shows all the virtues (concept, historical maps) and shortcomings (toponymy, ubiquity, ethnogenesis) of Rajić as a historical geographer (Мишић, 2003).

\section{Beginnings of Serbian geography and cartography in the $19^{\text {th }}$ century}

Stefan Stratimirović (Kulpin, 1757 - Sremski Karlovci, 1836), Bishop of Budim from 1786, and since 1790. Metropolitan of Karlovac. Otherwise, he was a student and friend of Jovan Rajić and began to study more geography. In this regard, he supplied the Patriarchal Library with rare books and maps. He studied the works of Strabo and Constantine Porphyrogenitus, and "collected in his famous library almost all the former geographical maps of the Serbian lands and tried to bring that dead and uncertain knowledge to life and establish it by oral news" (Петровић, 1997). From more discerning nuns he collected geographic information from various places. For example, from Arsenije, the archimandrite of the Piva Monastery, he received descriptions of Herzegovina and its rivers in 1803 and 1804, in 1804 he obtained information on rivers, mountains and areas in eastern Serbia and other regions from Atanasije Droha (Радојчић, 1927). On the basis of the collected material, Stratimirovic provided "certain geographical data on Serbian lands (1803 and 1804)" (Јовановић, 1958). Although an enthusiast and lover of geography, he still failed to write a major work on Serbian lands.

Pavle Solarić (Velik Pisanica near Bjelovar, 1779 - Venice, 1821), was a student and follower of the great Serbian enlightener Dositej Obradović. For him, Skerlić wrote that he was "a moralist, archeologist, linguist, geographer and writer". He published in Venice in 1804 a two-volume "Novogradjanski zemljopis", first geography on the Serbian language (Ново гражданско землеописание. Перво на езику сербском), which Skerlić says is "a great work” (Петровић, 1997). Inspired probably by the atlases of Ortelius and others, Solarić says: "Earthwriting - extensively narrated - is the most magnificent theater, it is a mirror of the world" (Ристић, 1957). Solarić's book was printed in two parts on 720 pages with the wholehearted help of Dositej. In preface, Solarić states that his work is supplemented translation of Adolf Christian Gaspari's book "Allgemeine 
Einleitung in die neueste Erdbeschreibung". In 1804, Solarić also issued the first geographical atlas on Serbian language with 37 maps. Serbia with Kosovo was portrayed as part of what was then Turkey on only one page, and Montenegro on the half page. Of the larger settlements, only Belgrade, Šabac, Smederevo, Požarevac, Hasanpašina (Smederevska) Palanka and Niš were mentioned, while Kragujevac was not recorded (Popović, 1954).

Sava Tekelija (Popović) (Arad, 1761 - Pest, 1842), the first Serbian doctor of law, a wealthy intellectual with noble privileges, a benefactor and lifelong president of Matica Srpska. He was one of the figures who marked the $18^{\text {th }}$ and the first half of the $19^{\text {th }}$ century in the history of Serbian culture (Павловић, 2007). Hе was also recognized as the first Serb to compile the first map of Serbian countries and "printed in Serbian", in Vienna in 1805, under the heading "Земльображенніе Србске, Босне, Далмацие, Дубровне, Црнегоре и ограничних предял". The тар was made in copper cut in 1:1.000.000 scale and printed in 2.000 copies. Part of the circulation was sent to Serbia to assist the Serbian uprisings in the fight against the Turks, "in order to help to orient themselves". In 1805, Tekelija wrote: "It was in my mind to make a map of Serbia with Cyrillic letters that Serbs could read it". It depicts the relief (shaded molehill method), hydrographic network, settlements and borders. Toponyms are written in civilian Суrillic (Радошевић, 1974). As on older European geographical maps, Serbia is represented within its geographical borders, including Prizren, Priština, Vučitrn, Skopje, Kratovo, Pirot, Caribrod (Stari Brod) and Custendil. The Constantinople road was also drawn. Tekelija's map of Serbia was created by compilation "from various maps, and above all the maps of Carl Schutz: Neueste karte der Koenigreiche Bosnien, Servien, Croatien und Slavonien samt den angraenzenden Provinzen...from 1788 and 1802 године (Радојчић, 1927; Ракићевић, 1996).

Vuk Stefanović Karadžić (Tršić, 1787 - Vienna, 1864), a great Serbian enlightener, noted that at the beginning of the $19^{\text {th }}$ century, Serbian people and Serbian countries were poorly studied geographically and ethnographically, as "terra incognita" in Europe. With "Humbolt's", i.e. field methods and observations, or as he puts it "in his own observation" and on the basis of "undoubtedly reliable and original sources" (Караџић, 1927), Vuk has succeeded "somewhat beyond the level of geographical exploration of his time" (Васовић, 1987), especially in the domain of anthropogeography, and can rightly "be considered the pioneer of this scientific branch" (Лутовац, 1966). "Great merit of cooperating geography, history and ethnography belongs to Vuk" (Вукановић, 1947). Austrian Captain Weingarten wrote a paper on Serbia with a map attached in 1820, and was immediately followed by Karadžićs s criticism. Namely, Weingarten marked on its map the geographical borders of Serbia, which included some as still not-liberated settlements of Novi Pazar, Vučitrn, Banja, Priština, Kuršumlija and Prokuplje, and in the southeast Niš, Leskovac, Vranje 
and Novo Brdo. Outside these borders he omitted Pirot and Metohija with Peć and Djakovica, Nova Varoš and Sjenica. Vuk suggested that, as Weingarten already wanted to draw Serbia's borders wider than the Belgrade Pashaluk, he should not have left out "Metohija (where Prizren and Peć and Djakovica are). Then it should be indicated on the entire map of old Serbia with different color border of the Belgrade Pashaluk". Vuk was the one who first mentioned the term "Old Serbia" (alte Serbien) as well as in a critique of Weingarten's writings and maps in the Austrian journal Erneuerte vaterländische Blätter fürden österreichischen kaiserstaat (Шешум, 2015, 2015). Vuk's "Српски рјечник" (Serbian Dictionary) (1818 and 1852) contains explanations of many geographical toponyms and terms, so it can be considered as "the first geographical lexicon in us" (Ракићевић, 1995). In the first edition of the Српски рјечник (1818), he stated that the towns of Djakovica and Dečani, Niš, Novi Pazar and Prizren, and the Lab River were in Serbia. He mistakenly placed Peć in Albania, and labeled Vučitrn and Prilep as places "in Kosovo", which he also considered as part of Serbia, which can be seen in the statement on Sitnica, which he wrote was "water in Serbia, in Kosovo". He placed Skopje in Macedonia. In the second edition of the "Рјечник" from 1852, Vuk placed Tetovo, Prilep, River Vardar, Kačanik and Polog, Peć and Čičavica in Old Serbia and Prizren, Rožaj, Šar Planina, Vranje and Novi Pazar in Serbia. He placed Debar and Skopje in Macedonia, but said that in Debar and Kičevo, Christians speak Serbian, which is a little similar to Bulgarian. In 1857, he stated that "Macedonia" would be a synonymous expression of "Serbian land" and "all countries of our people were called Macedonia" (Шешум, 2015). Vuk published Географическо-статистическо описаније Србије (Geographic-Statistical Writing of Serbia) in the Danica magazine for 1827 in Vienna, with a geographical map attached (Караџић, 1827). Vuk used some wrong names for mountains and rivers he took from Milosević's translation of Weingarten's description and a map of Serbia. The names for the villages in the Belgrade pashaluk, in 13 nahia, Vuk was transcribed from the tax book from 1822 (Петровић, 1997). Other Karadžic's work of anthropogeographical and ethnographic character, "Montenegro und Montenegriner", published in Stuttgart in 1837, concisely and informative, was well received by a German reading public, so Kopitar writes to the Vuk: "It is your fault that now the whole world, even the kings themselves, travel to Montenegro and Serbia" (Стојановић, 1922).

Stevan Milošević, an Austrian frontier officer in service in Nova Gradiška, translated Weingarten's geographical work Über Serbien into Serbian and printed it in Budapest in 1822 under the title "Statistic Description of Serbia (with a geography of this land)", (Штатістіческое описаніе Сербіе (со землеописаніем ове земль). Milošević approached this work out of patriotism, emphasizing in the preface that "there is nothing more urgent to Serb from becoming acquainted with Serbia's past and present" (Радојчић, 1927). In addition to that, he also 
published a map "Geography of Serbia" (Землепис од Сербие) in scale 1:835.000, which is actually a Serbian translation of Weingarten's map. Although the translation has many errors, Cvijić praised it positively (Цвијић, 1889a).

Dimitrije Momirović Stojanović, a Serb in Russian service, published a map of Serbia in his Russian language paper "Краткая исторія и географія Cербiu" in Petrograd (1839), which he dedicated to Russian Emperor Nikolai I. He praised, but also took a lot from Vuk Karadžić. The map of Serbia, which is attached with the book, has a sense of respect for Weingarten's map, especially when it comes to orographic relationships (Петровић, 1997).

Jovan Bugarski, born in a Serbian family in southern Hungary between 1800 and 1810, an engineer with a degree from the University of Budapest (1838), was a civil servant in Belgrade between 1839 and 1844. He produced the first geographical map of the Principality of Serbia (Княжества Србіе) in 1843 (Мишић, 2001). Bugarski and Anastas Jovanović, who did the lithography, published the map in Vienna in 1845 and dedicated it to the then already former prince Mihailo Obrenović, whose first reign lasted from 1839 to 1842 . One version of the map was printed on French (Шкаламера, 1991; Томић, 2018). The map contains a tabular overview of the 17 districts (окружія) that are divided into counties, and for each district the number of villages and population is given. All things considered, Serbia had about 2.050 settlements and 936.050 inhabitants. The legend of the map contains a series of signatures showing the types of borders, types of settlements (cities, towns, little towns, villages and hamlets), roads, rivers and streams, and there are signatures for border posts, monasteries, baths, spas, post offices, mines of gold, silver, copper, iron, lead. The relief is represented by hatching. The scale is 1:345.000, and it is given in Russian species, Turkish and geographical miles. In 1895, Cvijić observed that on the Bugarski's map "the names are somewhat more accurate, but the basis of the map and orography are very wrong" (Цвијић, 1894; Петровић, 1997; Живковић, 2012). “It can be seen at a glance that Bugarski did not know the country and the people south of the border of the Principality" (Терзић, 1997). Bugarski has labeled still not-liberated territories of Novopazarska nahiyah, Kosovo and Metohija as the "Honor of old Serbia, present Albania", which borders Bulgaria south of Niš. The famous German cartographer Kipert refers to the Bugarski map in the subtitle of his map of Serbia (1849).

Jovan Milenković, an official at the State Council, was accompanied by Russian General Staff Captain Kocebu as a connoisseur of "most of Serbia," and allegedly covertly copied his map, and used that copy twenty years later as the basis for compiling the first official map of the "Кьажевство Србіе" (Principality of Serbia) at a scale of 1:300.000. The original draft of the Milenković map entitled "Erster Versuch einer Karte von Serbien 1830 von Milennkovitsch" was retained by General F. Zah in his library, which he donated to the Military Academy in 
Belgrade in 1881. The map was issued in Belgrade in 1850, measuring 112 × 85 $\mathrm{cm}$ on four sheets. In the lower left corner of the map is a list of districts (okruzi) with village names and population, and in the right corner of the map is a list of counties (srezovi). The map has long been used in schools (almost 50 years) (Шкаламера, 1991; Живковић, 2012). Anta Aleksić, in his work “Gradja za kartografiju i geografiju Srbije" (Materials for cartography and geography of Serbia) (1883), stated that J. Milenković is "our first cartographer". Misconceptions about the still not-liberated Serbian regions and countries in the south reflect not only the ignorance of Serbian countries in the first half of the nineteenth century, but also the unconditional acceptance of narrowed representations by foreign researchers about the entirety of Serbian ethnic space (Терзић, 2008).

\section{First travelogues on Serbian language and geography teaching aids}

Joakim Vujić (Baja, 1772 - Belgrade, 1847), travel writer and founder of the first theater in Serbia (in Kragujevac, 1826), published in Budim in 1825 a "Новъише землеописаніе иуглаго сьгта" ("A new geography of whole world"), probably a translation of some foreign work (Ракићевић Т., 1995). At the end of 1826, Vujić embarked on a six-month trip to Serbia, and then in 1828 published in Buda a valuable travelogue entitled "Путемествiе по Сербіи" ("Traveling in Serbia") (Вујић J., 1999).

Georgije (Djordje) Magarašević (Adaševci, 1793 - Novi Sad, 1830), writer and professor, traveled to western Serbia and published "Путоваюа по Србији у 1827. години" ("Travels in Serbia in 1827").

Jovan Gavrilović (Vukovar, 1796 - Belgrade, 1877), published in Belgrade in 1846 the first work of an encyclopedic-statistical character on the population and settlements of Serbia: "Речник географијско-статистични Србије" (Geographical-Statistical Dictionary of Serbia"). The dictionary was compiled on the basis of a list of tax from 1844 and is a valuable source of information about the Principality of Serbia. The dictionary contains determinants of settlements, significant rivers and mountains, districts, counties, dioceses, etc. (Гавриловић, 1994; Петровић, 1997).

Gedeon Josif Jurisić (Irig, 1809-1872), a jeromonk who stayed in Visoki Dečani Monastery for several years and undertook trips to the surrounding areas. In his book "Дечански првенаи", published in Novi Sad in 1852, gave basic information about the country, monuments and people. He spatially defined the term "Old Serbia" by which he refers to these nahiyas: Novi Pazar, Peć, Djakovica, Prizren, Skopje, Kosovo, Priština, Vučitrn, Vranje, Leskovac and Niš (Терзић, 2008). 
Governorship in Serbia, encouraged by the circumstances of church-political and cultural struggle (on the occasion of the Bulgarian exarchy), recognizing that ethnographic and cultural circumstances in the southern regions are poorly known in Belgrade, established in 1868 a Committee on schools and teachers in old Serbia, in which Archimandrite Nićifor Dučić, Miloš S. Milojević and Panta Srecković entered (Терзић, 2008).

\section{First school maps}

Until the middle of the $19^{\text {th }}$ century, there were no school wall maps in Serbia in native language. The Ministry of Education hired in 1853/4. Viennese cartographer, Professor Constantine Desjardins (1787-1876), who already made maps for educational institutions in Europe and applied modern methods of lithography, to produce several school geographical maps of Serbia and neighboring countries, Europe and the world in different proportions. In 1853, Desjarden produced two wall maps. These are: 1) Школска мапа Княжества Старе и Войводине Србіе, Босне, Ериеговине и Црнегоре, Славоніе, Хрватске и Далмаціе съ неким частима други Аустрійски областій, Албаніе, Македоніе, Бугарске, Влашке (School map of the Principality of Old Serbia, Bosnia, Herzegovina and Montenegro, Slavonia, Croatia and Dalmatia with some other Austrian territories, Albania, Macedonia, Bulgaria, Wallachia) in medium size [1: 655.000], dimension $133 \times 100 \mathrm{~cm}$, which covers a similar space as Tekelija's map; and 2) Школска мапа Европске Турске са Србіомъ и Влашкомъ (A school map of European Turkey with Serbia and Walachia), [1:950.000], measuring $130 \times 100 \mathrm{~cm}$. The Serbian government also ordered geographic maps of continents and planiglobes from the same cartographer, which were made in 1853. In 1854, Déjardin produced a "Amıac земьописни" (Geographical Atlas) with ten maps, dimensions $34 \times 27 \mathrm{~cm}$, and in 1855 he made a School Map of Europe on a small scale [1: 3.100.000]. These were the first school maps printed at the Government Stonecutter's Office in Belgrade, which "along with Milenković's map of Serbia, which was also used in schools, significantly improved geography teaching and contributed to its popularization" (Шкаламера, 1991). Desjardins has introduced on his maps the name Old Serbia in its narrow sense, which covers only the northern part of Kosovo, excluding Metohija, Toplica and South Pomoravlje (Терзић, 2008).

\section{First regional maps in Serbia}

Maps of individual areas of Serbia began to appear in the mid-19 $9^{\text {th }}$ century. Nikola Vasojević published a "Семитипографску карту Кьуча или окружја Крајинског" ("Semitipographic Map of the Ključ or District of Krajina") (1844) 
and „Земьовид Косова поља“ ("Map of Kosovo Polje”) [1: 200,000], in Novi Sad (1847). Glasnik Društva srpske slovesnosti (Bulletin of the Society of Serbian knowledge), published a series of maps of individual districts of Serbia, in the ratio of 1:100.000 or 1:200.000, which are based on data obtained from their own field measurements (Дукић, 1989). The first in this series is Карта окружія Пожаревачкогъ (Map of Požarevac District) published by A. Medović in 1852. A. P. Ivanović published the paper Описание окружја Краинског (Description of Krajina District) (1853), with a map attached. Then, Ilija Pčelar had published Карту окружія Крайинскогъ (Map of Krapina District) (1856), Stojan Obradovic Карту окружія Ужичкогъ (Map of Užice District) (1858), Jovan Mišković Kapmy окружія Рудничког (Map of Rudnik District) (1872), Mihailo N. Ilić Kapmy Oвчара u Каблара (Map of Ovčar i Kablar) (1875) in the scale of 1:75.000. These are maps with a wealth of information on local occasions relating to settlements, roads, rivers, monasteries, churches and cultural and historical monuments.

Jevrem Marković, a lieutenant (Zaječar, 1839 - Arandjelovac, 1878), produced a map of the Knjaževac district (Кюажевачког округа) (1870) in a scale of 1: 200,000, on which the relief was "shown for the first time in Serbian cartography with contour lines", with black color, as well as borders and settlements, while the main road and other roads are highlighted in red, the rivers with blue and "crossings" are highlighted in yellow. On the scale at the bottom, distances are marked in meters, and from above in hours of walk (1 hour $=4 \mathrm{~km})$ (Радојчић, 1997).

Stevan Mačaj (Budim, 1829 - Belgrade, 1889), a doctor originally from Hungary, produced a map of the Knjaževac district in the scale of 1:200.000 based on Jevrem Marković's sketch, and attached to his work on that district in the Bulletin of the Serbian Learned Society (Mačaj, 1866). The map is color-coded, aesthetically beautiful, but has no cartographic network, elevations, or equidistance between isohypses, so distances on the map are arbitrary. The names of some of the more important watercourses are also missing. There are mistakes in marking the position of some mountains and settlements. There are seven cartographic signs in the legend, but there are no signs for border posts and monasteries, which are on the map (Сибиновић, 2011). In this first study on the Knjaževac region, Mačaj provided a wealth of data from various scientific fields. He gave the first information about the ancient city of Timacum Minus, located on the site Kulina in the village of Ravna (Илијић, 2015).

Jovan Miškovic (Negotin, 1844 - Belgrade, 1908), general and academic, minister of the military and president of the Serbian Royal Academy, founder of Serbian military geography. He made a Hydrographic Map of the Principality of Serbia (1880) and the Topographic Key of the Jagodina District (1885). He noticed the drawbacks of the S. Mačaj map and on the basis of the map of the Austrian General Staff of 1879 in the scale 1:300.000, produced a new map of the 
Knjaževac district in the scale of 1: 200.000 (Mišković, 1881). He provided a geographical map of the Rudnik District in the scale of 1:200.000 with the scientific paper „Опис Рудничког округа“ (Description of the Rudnik District) (1872), in which he gave information on the orographic and hydrographic characteristics of the area. He published the Map of Kosovo Polje (1900), in a scale of 1: 150.000. General Miškovic dealt with geographic-topographic descriptions of the terrain primarily as a military expert, for military-strategic reasons, but also as a geographer and scientist.

Jovan Dragaševic (Požarevac, 1836 - Niš, 1915), "the first Serbian military geographer, later honorary general and a member of the Serbian Learned Society". He taught Comparative Geography with Ethnography at the Great School from 1885 (Грбић, Јордановић, 2018). He produced a Map of Mlava, Pek and Homolje in 1876, where the relief was depicted by the method of height layers in tones of the same color (Радојчић, 1997). As a military expert, Dragaševic was in the Serbian delegation to the Berlin Congress in 1878 (Јововић, Шуљагић, 2016). On that occasion, he enclosed an ethnographic map Carte etnographique de la Presque'ile des Balkans dressee d'apres les documents historique et presque'ile (1885) with the text Notice statistique sur le Peninsule de Balkans. He published this text and map in the Serbian journal "Warrior" for November 1879.

\section{First thematic maps in Serbia}

Ethnographic maps came into focus in the $19^{\text {th }}$ century regarding the creation of nation-states in the Balkans. Such maps displayed often diametrically opposed views on the ethnicity of particular ethnic groups and the delimitation of boundaries in ethnocontact zones (Wilkinskon, 1951).

Dimitrije Davidović (Zemun, 1789 - Smederevo, 1838) published the first ethnographic map "Земль у коима пребиваю Серблы" (States in which Serbs reside) (Давидовић, 1821). A second map under the same title appeared in the 1846 edition of Davidović's book, "The History of the Serbian Nation". Guided mainly by the native language as a criterion for ethnic identity, Davidović indicated in green the areas populated by Serbs: Gorski Kotar, Lika, Banija and Kordun, Slavonia with Srem, Bačka, Western Banat, Bosnia and Herzegovina, Dalmatia, Montenegro and Serbia including Sandžak and Kosovo. South Pomoravlje and Ponišavlje, part of Metohija with Prizren, the coast around Bar and Ulcinj are omitted. Dashed lines and yellow indicate national and administrative borders. The aforementioned Professor Desjardins, in 1853, published in Belgrade map "Србія и землть у коима се сербскій говори са неким частима пограничніи земаля" (Serbia and the countries in which Serbian is spoken with some borderlands), based on Davidović's map. 
Jovan Djordjević (Senta, 1826-1900, Belgrade), a writer who worked on awakening the national consciousness of Serbs in Vojvodina (among other things, he founded the Serbian National Theater in Novi Sad, wrote the text of the anthem of the Kingdom of Serbia "Bože Pravde"), on the proposal of the Annunciation Council in which he participated as a Member of Parliament, he produced in 1861 a Map of Srem, Bačka and Banat [1: 595.000], in order to present the political and territorial demands of that assembly for the "Vojvodovinu srbsku”. In the book „Радња Благовештенског Сабора 1861“ (The Work of the Annunciation Assembly of 1861), he says that the map was made "according to Friedberg's big map. It identifies all the places that belong to the projected Vojvodina, and beyond it all other larger and major places" (Ђорђевић, J. 1861). The map contains an Austrian mile marker, toponyms written in cyrillic and "a legend with signs for towns, cities, monasteries, post offices, borders, roads" (Јовановић, 2012).

Miloš St. Milojević (Crna Bara, 1840 - Belgrade, 1897), studied as a "national cadet" at Moscow University from 1862-1865, where he earned the title of "Candidate of historical and philological sciences". On the same faculty, with the same professor (O. M. Bodjanski), from 1861-1865. famous Bulgarian historian Marin Drinov has studied (Drinov, 1971, p. 10). Milojević understood the intentions of Bulgarian propaganda backed by Russian Slavophiles and devoted him to the study of the history and ethnography of not yet liberated Serbian countries. He produced a map „Историско етнографрско географска мапа Срба и српских (југословенских) земаља у Турској и Аустрији“ (Historical and Ethnographic Geographical Map of Serbs and Serbian (Yugoslav) Countries in Turkey and Austria) [1: 2.000.000], issued in Belgrade in 1873. The map was printed on four sheets with a total size of $153 \times 118 \mathrm{~cm}$. It looks representative, colored and decorated with 40 coats of arms, with plenty of details. The map was well received by supporters of Pan-Slavism in Austro-Hungary, but it also provoked Serbophobic interpretations as "Greater Serbian" propaganda (Wilkinson, 1951).

Nićifor Dučić (Lug, Trebinje, 1832 - Belgrade, 1900), archimandrite, Serbian historian and member of the Serbian Royal Academy, drew up in 1874 a schematic map of Montenegro within the limits set by the Commission in 1859-60. He published it with paper "Montenegro" in the Bulletin of the Serbian Learned Society, Belgrade (Дучић, 1874).

Matija Ban (Petrovo Selo near Dubrovnik, 1818 - Belgrade, 1903), a Dubrovnik resident who lived and worked in Belgrade as a writer, professor at Lyceum and a member of the Serbian Royal Academy. In his study of the Eastern Question, he enclosed a thematic map of ecclesiastical jurisdiction in the Balkan Peninsula entitled "Carte des anciens patriarchats Grec, bulgare et Serbe, d'apres les document officials" (Ban, 1885). The map is overview, measuring 27x41.5 cm. 
Dragiša Žegligović, Professor of Geography and Ethnography, published the Ethnographic Map of the Balkan Peninsula (1885). Vladimir Karić, published a Map of the spreading of Serbs, in the book "Serbia" (1887), but without much echo.

Spiridon Gopčević (Trieste, 1855 - Berlin, 1937), a Serb from Trieste, whose family is originating from Herceg Novi, completed a conservatory and "historical-geographical and military-political studies" in Vienna. He is the author of numerous extensive geographic and historical monographs, first published in German: Montenegro and Montenegrins (1877), Upper Albania and its League (1881), Old Serbia and Macedonia (1889), History of Montenegro and Albania (1914), Russia and Serbia 1804-1815 (1916) and others. Gopčević's books are real "ethnographic gems". His two-volume book, Old Serbia and Macedonia (1889), published 500 years after the Battle of Kosovo, details the lives of residents "from Skopje to Thessaloniki and from Priština to Veria" and the customs of the Serbian people in the area (Митровић, 2009; Михаиловић, 2016). It is an "impressive ethnographic work, illustrated with beautiful drawings and photographs", accompanied by an ethnographic map of Old Serbia and Macedonia (Alt Serbien und Makedonien) in the scale of 1:300.000. It was the first largescale ethnographic map of Old Serbia and Macedonia. Based on dialectological and ethnographic research in the field, Gopčević corrected the Austrian maps in many topographic details and introduced about 2.000 new terms (Гопчевић, 1889a). The map appeared under the auspices of the Military Geographical Institute in Vienna (Militar.-Geographisches Institut k. Und k. In Wien). The same year, in Petermann's Mittheilungen journal was published the same map at a scale of 1:750.000, as a contribution to the paper "Die ethnographischen Verhältnisse Makedoniens und Altserbiens" (Gopčević, 1889b). By publishing in this renowned journal, the map has received wide publicity and its author has gained a reputation among European scholars (Yosmaoğlu, 2013). Gopčević's methods of making an ethnographic map signified an improvement over the usual methods of the time. Like Karl Sax, he emphasized religious differences and introduced symbols to represent the ethnic structure of the population of major cities. Overall, he distinguished between twelve ethnic groups in Old Serbia and Macedonia. According to Gopčević, the border between Old Serbia and Macedonia runs south of Bitola and Strumica. His key argument is the linguistic factor and also folklore and history. He states a number of similarities between the Macedonian and Serbian dialects and concludes that Bulgarians inhabit a very small part of Macedonia (Wilkinson, 1951).

\section{The first engineering maps and plans}

Jovan Žujović (Brusnica, 1856 - Belgrade, 1936), founder of Serbian geology, after completing his studies in Paris, was a professor at Belgrade University and 
an academic. He wrote "Основе за геологију Краљевине Србије“ (Fundamentals of Geology of the Kingdom of Serbia) (1886), „Геологија Србије“ (Geology of Serbia) (1893), „Топографска геологија“ (Topographic Geology) (1893), and produced "the first geological map of the Kingdom of Serbia in 1886", thus joining Serbia to a small number of European countries that have been geologically explored"(Царевић, 2015). His map of the Geologische Ubersichtskarte des Konigreiches Serbien [1:750.000] was published in the Yearbook of the Vienna Imperial Geological Survey, 1886.

Antonije Anta Aleksić (Pančevo, 1844 - Belgrade, 1893), hydrologist, military geographer and cartographer, made a plan for the surrounding area of Belgrade based on his own recordings (1865-66) in the scale of 1:50.000. He also recorded the Morava valley from Bagrdan to Kruševac at a scale of 1:200.000 (Алексић, 1876). In his work „Мачва, са нарочитим погледом на поплавне прилике (са географском картом)" (Мас̌va, With a Particular View of the Flood Conditions (with a Geographical Map)) (1891), Aleksić also submitted the first Hydrographic Map of the Mačva, for the melioration and hydrotechnics purposes (Алексић, 1891). The map shows meandering river flows, meanders, still waters, wetlands, and drainage of the terrain.

\section{The first general geographical maps and monographs on Serbia}

Staff Captain Ljubomir Ivanović, on the basis of terrain survey by Husard's compass taken by the army, compiled in 1869 a "Опиту географску карту Cрбиje" (General Geographic Map of Serbia) in the scale of 1:500.000. The map was used under secrecy by the Serbian army in the war against Turkey in 18761878, and later until the release of the Serbian General Map. This map was used, with permission, by the Military Geographical Institute in Vienna for the development of their General Map at a scale of 1: 300.000 (Generalkarte von Bosnien und Herzegovina, von Serbien und Montenegro, 1876).

Milan Đ. Milićević (Rtanj, 1831 - Belgrade, 1908), a Serbian historian and ethnographer, wrote historical-geographical works "Кнежевина Србија" (Principality of Serbia) (1876) and "Краљевина Србија" (Kingdom of Serbia) (1884), with geographical maps attached, which brought new topographic information and new insights into archaeology and local lore. The Principality of Serbia provides a wealth of material for history, historical geography and ethnology. In this extensive work with lots of geographical information, were described orography, hydrography, topography, archeology, history, ethnography and statistics of the then Serbia.

Vladimir Karić (Svetlić, Kragujevac, 1848 - 1894, Baden, Austria), Serbian geographer and diplomat, is the author of the book „Србија - опис земье, народа 
и државе“ (Serbia - Description of Country, People and State) (1887), which was exhibited at the World Exhibition in Paris (1889). The foreign press reported that "Karić erected the most beautiful monument on his homeland in the Paris Exhibition, with his beautifully made book" (Станковић, 2012). In that capital work, Karić published six maps and 19 cartograms. Karić's most significant geographical maps are the Balkan Peninsula 1:1000000 (1883) and the Serbian countries and the Balkan Peninsula at a scale of 1:3000000, published by M. Jorgović in 1884, as well as map Краљевина Србија (Kingdom of Serbia) (1887), on which Old Serbia encompasses the then Kosovo Vilajet (province), from Pljevlja and Tara, to the southern surroundings of Skopje.

At the end of the $19^{\text {th }}$ century, expansion was experienced by commercial maps, which contributed to the expansion of the map publishers and the popularization of the geographical map as a means of communication. Such are the maps: M. St. Ubavčić: Map of Dušan's empire, 1:3000000 published in 1885; Bešlić: Map of Serbian Countries 1:2000000; Map of the Kingdom of Serbia, 1:1500000 published by Valožić's Bookstore; M. Jorgović: Kingdom of Serbia, 1:1500000 published in 1885; Map of the Kingdom of Serbia, 1:800000 published by Mita Stajić's court bookstore (Шкаламера, 1991).

\section{First surveying and military topographic maps}

The Military Geographical Institute in Belgrade takes the date of its establishment and at the same time, as the beginning of the development of the military geodetic service on February 5, 1876, when the Second Department of the Main General Staff of the Serbian Army was formed in order to "carry out tasks related to the military surveying of Serbia, to draw up the necessary military maps, to survey and make various military plans, to observe and study the country, own and neighboring in terms of geography, topography and statistic" (Радојчић, Срдић, 2012). The Second department was renamed the Geographical Division at the General Staff in 1878. Until then, Serbia did not have a large-scale map of its territory or a map created by measurement, so the Geographical Division of the General Staff from 1881 to 1892 measured Serbia at a scale of 1:50.000 and produced the first topographic maps at a scale of 1:75.000, in multiple colors with isohips, which represented an improvement over the Austro-Hungarian maps that were made in the same scale in black shadowing technique. The Topographic Key and the Map of the South Morava Basin - middle part [1:300.000] were printed in 1881, which shows the territories annexed to the Principality of Serbia by the decisions of the Berlin Congress in 1878. It was the first map of the Military Geographical Institute (Бошковић, 1930; Радојчић, Срдић, 2014). The first topographic land survey of 1: 50,000 and production of 
military maps of Serbia were carried out by 29 general staff officers, including the then Major Stepa Stepanović, Živojin Mišić and Petar Bojović, later Field Marshals and celebrated military leaders. This survey was later used by Jovan Cvijić for his 1:75000 map, and Deroko for making his 1:1000000 (1911) and 1:200.000 (1913) maps (Бојовић, 1997). Along with topographic land survey, new maps were successively issued. At the end of that great work in 1893, the first map drawn on the basis of the topographic land survey: "Бенералитабна карта Краљевине Србије" (General Staff Map of the Kingdom of Serbia) in the scale of 1:75.000, on 95 sheets in five colors was completed. Cvijić made critical remarks on this map, especially regarding the accuracy of the altitudes and the position of some toponyms (Радојчић, Бакрач, Амовић, 2015), but also emphasized that "it differs much, too much from the whole past cartography" (Цвијић, 1889б). In the same year, the General Staff Map of the Kingdom of Serbia [1:200.000] was published on nine sheets. In 1895 was published new map in a scale of 1:250.000, the same on nine sheets in five colors, with relief shown in shadowing technique "thus completing a small system of topographic maps", for which Cvijić wrote that they "form a separate period in the development of cartography in Serbia" (Вемић, 2007). These maps signified the great advance of Serbian cartography and were used in the Balkan wars and in the First World War. Also, in 1893 a Map of postal, telegraphic and railway communications (Carte des communications postales, telegraphs and des chemins de fer du Royaume de Serbie, 1: 500.000) was issued, and in 1898 а Карта околине Београда (Мар of the Belgrade area) and План Крагујевияа и околине (A plan of Kragujevac and its surroundings) (1:25.000). In 1912, the Geographical Division of the General Staff was renamed the Topographic Division of the Supreme Command. During the First World War, this department produced a Topographical Map of the South Slavic countries, 1:200.000, on which these countries were first shown as a whole (Бакрач, Радојчић, Ђорђевић, 2015). In the Kingdom of Yugoslavia, in 1920, the Geographical Institute of the General Staff was formed from the Topographic Department, which in 1923 was named the Military Geographical Institute (Vojnogeografski Institut-VGI), which worked between two World Wars on topographic land survey of the newly formed Yugoslavia. Its capital work was Topographic Maps 1:50.000 and 1:100.000, respectively, which were completed in 1933. They were made in polyhedral projection with the initial Paris meridian, with isohips and equidistant of $20 \mathrm{~m}$. This topographic map was stamp in scale 1:25.000 too, but was not completed due to World War II. Before the war, an overview map of 1:500.000 was issued in Tiso's projection and with relief presented in layers (Радошевић, 1974; Анђелић, 1990). After the Second World War, the Military-Geographical Institute worked on a new topographic-photogrammetric survey of Yugoslavia in the scale of 1:25.000, and after that on the development of a scale system of new topographic maps, development and up- 
dating of overview-topographic, thematic and special maps, performed on the basis of the new topographic land survey (Бакрач, Радојчић, Секуловић, 2016). The Military-Geographical Institute participated in major Yugoslav cartographic projects such as the Basic Geological Map of Yugoslavia at a scale of 1:100.000 and a series of Overview geological maps (geological, hydrogeological, engineeringgeological, oil and gas, mineral and thermal waters maps) at a scale of 1:500.000, Basic Pedological Map 1:50.000, Climate Atlas of Yugoslavia 1:1.000.000, Agroclimatic Atlas of Yugoslavia 1:1.000.000.

Stevan P. Bošković (Zaječar, 1868 - 1957, Belgrade), general and chief of the Geography Department, opened a new chapter in the history of geodesy in Serbia (Радојчић, 1998, 2014; Радојчић и Срдић, 2014). He is one of the founders of the Military Geographical Institute where he organized the making of a topographic map of Serbia and Montenegro and Macedonia in the scale of 1:50.000 and its reproduction in the scale of 1:100.000 (Савић, 1987). During World War I, Bošković formed the Topographic Division of the Supreme Command in Thessaloniki, in 1916, and succeeded in issuing a series of maps and plans of the Thessaloniki Front (1:5.000, 1:10.000, 1:25.000, 1:50.000 and 1:200.000) who have raised the reputation of the Topographic Profession in the eyes of the Allies (Бакрач, Радојчић, Ђорђевић, 2015). He published a series of cartographic-geodetic works and geographical maps: Map of the Serbian Kingdom 1:1.000.000 (1914); A new map of Serbian kingdoms and neighboring areas in a scale of 1:1.000.000, with relief depicted by a hypsometric scale (1914); Map of Timok Region 1:500.000 (1930); Map of the Kingdom of Yugoslavia 1:1.000.000 (1931-1938); Map of Timok Region 1:500.000 (1934); FNR Yugoslavia Overview Map 1:500.000 (1952). He was one of the founders and the first vice president of the Serbian Geographical Society in 1910.

\section{Jovan Cvijić and his School of Geography and Cartography}

Jovan Cvijić (Loznica, 1895-1927, Belgrade), founder of contemporary geographical science in Serbia and founder of the Geographical Institute, 1893 (Дукић, 1985) and the Serbian Geographical Society, 1910 (Станковић, 2012), provoked a scientific revolution in Serbian geography. In Cvijić's geopolitical visions, because of their neighborhood and transitional position, cultural and civilizational influences, South Slavic countries are part of the European cultural space (Грчић, 1996), but they cannot be subsumed under one culture. In this regard, he advocated the unity of the South Slavs and all-Slovenian solidarity, while respecting the cultural specificities and identity traits of particular ethnoses (Грчић, 2014), which some ignorant authors today misinterpret as "Greater Serbian ideology". Cvijić remained remembered, according to Jirzi 
Danes, dean of the Faculty of Natural Sciences in Prague, as "one of the greatest scientific travelers and expert geographers of all time" (Станковић, 2019). Не has received numerous honors, including the Medal of Geographical Societies in London, New York, Paris, and the Charles University Medal in Prague and Sorbonne in Paris. The path to the scientific cartography in Serbia was cleared by Cvijić (Вемић, 2007). There are about 70 cartographic works in his oeuvre (Милојевић, 1927; Сретеновић, 1985; Вемић, 2005). Two atlases are particularly significant - "Геолошки атлас Македоније и Старе Србије" (Geological Atlas of Macedonia and Old Serbia) and atlas "Jезера Македоније, Старе Србије u Enupa" (Atlas of Lakes of Macedonia, Old Serbia and Epirus), published by the Serbian Royal Academy (1902). Besides that, some Cvijic's maps are significant too: Map of Serbia and Montenegro 1:750.000, (1897, 1898, and 1911); Map of the Kingdom of Serbs, Croats and Slovenes 1:500.000 (1922) and 1:1.200.000 (1922) (Милојевић, 1927). In addition to the above general geographical maps, there are also Cvijićs thematic maps - geological, geomorphological, ethnic and other (Петровић, Живковић, 1985).

Cvijić's Map of Serbia and Montenegro, in the scale of 1:750.000, was printed at the Military Geographical Institute in Vienna in 1897 and 1898. The map highlights the unfavorable geographical position and territorial separation of Serbia and Montenegro prior to the First Balkan War. These two countries are portrayed as two geopolitical islands surrounded by the Austro-Hungarian and Ottoman empires and separated by a "political isthmus". Serbia is portrayed as a "besieged country".

In "Политичко-етнографској скици Македоније и Старе Србије" (PoliticoEthnographic Sketch of Macedonia and Old Serbia) (1906), Cvijić pointed to the delicacy of the position of this then, still not liberated space. Unlike Gopčević, who believed that Macedonian Slavs were of Serbian descent, Cvijić and linguist Aleksandar Belić claimed that "only" Slavs in northern Macedonia were of Serbian descent, while those in southern Macedonia were identified as "Macedonian Slavs" or as "amorphous" Slovenian mass that is neither Bulgarian nor Serbian, but may be either Bulgarian or Serbian, depending on who rules the region" (Demeter, Bottlik, Czaplár-Degovics, 2015). Cvijić, in his research, found that "it is only natural that the Skopje, Kratovo and other parts of Kosovo vilayet will be named after the liberation of Serbia as Old Serbia. The notion of Old Serbia was not therefore created for national pretensions, and the southern borders of Old Serbia must extend beyond the Šar Planina, mainly to the area of present-day Kosovo vilayet" (Cvijić's italic) (Цвијић, 1906). In an Ethnographic sketch of Ancient Serbia from 1906, Cvijić divided the ethnoses by mother language into Serbs (blue), Arnauts (yellow) and Ottomans (red), and then divided them by religion, separating mixed areas and uninhabited areas. 
Cvijić's Ethnographic Map of the Balkan Peninsula, 1:1.000.000 (Etnographische karte der Balkanhalbinsel, Gotha, 1913), published in the prestigious Petermanns Mittelungen for March 1913, and in the Bulletin of the Serbian Geographical Society for 1913. A map with an explanation was intended to show ethnic relations in the Balkans and to serve as a basis for the withdrawal of ethnic borders after the Balkan Wars of 1912. The legend of the map combines the ethno-linguistic and religious principle of division. Another issue is that religious differences later outweighed the ethno-linguistic similarities and that the ethnic image of some landscapes changed due to ethno-demographic processes, ethnoengineering and population migration. Cvijić explains his ethnographic map: "An ethnographic map of no area in Europe is obsolete as quickly as an ethnographic map of the Balkan Peninsula. These are the areas where peoples are still in moving and creating and where every major war is the cause of migration, assimilation processes and other ethnographic changes".(...)“My ethnographic map is therefore of instant value, because it fixes the situation before the Balkan War and during the war. It is the last one to fix this situation and after a few years it will have only historical value, as a document on the basis of which it will be possible to trace the ethnographic changes made in the Balkan Peninsula" ( Цвијић, 1913). This map is included in many famous world atlases.

Cvijić, as a great scientific authority, has been involved in finding crisis exits and compromise solutions to border issues. During the First World War he participated in diplomatic missions and after the war he was chairman of the historical-ethnographic section of the Serbian delegation at the Peace Talks in Paris, where he played a significant role in determining the borders of the new Yugoslav state (Trgovčević, 1986, 1995; Prelić, 2014). He used his Ethnographic Map of the Balkan Peninsula, in the scale of 1:3.000.000 issued in French in Paris (Carte etnographique de la Peninsule des Balkans, Paris, 1918) and in English in London and New York. On the occasion of the Versailles Conference, Cvijić prepared a study on the northern borders of the Yugoslav countries with an ethnic map, maps of the Danube and Slovenian karst (Cvijić, 1919), in order to explain the right of the newly created Kingdom of Serbs, Croats and Slovenes to Istria, Trieste and Rijeka. After the Versailles Peace Conference of 1918, a new thematic cycle began in Serbian scientific geography and cartography. Cvijic's Map of the Kingdom of Serbs, Croats and Slovenes in the ratio of 1:500.000 and 1:1.200.000 was printed in Vienna in 1922 in cyrillic and latin variants. Thematic maps based on the 1921 census appear. For example, a Population Density Map of the Kingdom of the SHS by counties and a Population Map by religion in the Kingdom of the SHS were published in the Bulletin of the Serbian Geographical Society in 1923.

Cvijić was a great organizer of scientific work and founder of the first geographical institutions in the Balkans. He founded the Geographical Institute in 1893, the forerunner of today's Faculty of Geography, University of Belgrade, at 
which he gathered a large number of gifted associates. Radoje Dedinac, Stevan Bošković, Dragutin Deroko, Jevto Dedijer and Antonije Lazić stood out in the field of cartography.

Radoje Dedinac (Paraćin, 1880 -1913), a geographer and cartographer, finished high school in Sabac and geography studies at the Big School in Belgrade. He died as a Serbian soldier in the Second Balkan War near Kočan in 1913 (Пецељ, Станковић, 2019). Dedinac produced several maps representing progress in Serbian cartography: Map of the Principality of Serbia from 1815 - 1833 (Geographical Institute, Belgrade, 1901), Map of the Belgrade area (Geographical Institute, 1903), Map of Bosnia and Herzegovina (Circle of Serbian Sisters, 1909) and Plan of Belgrade 1815-1830 [scale 1:12.000], which was printed as an attachment to Joakim Vujic's book „Путешествије по Србији“ (Traveling in Serbia) (Лазар-Вукотић, Даниловић, 2015).

Jevto Dedijer (Čepelica, 1879 - Sarajevo, 1918). He graduated in high school in Mostar, studied geography in Belgrade and received his doctorate in Vienna in 1907 on the topic Das Hirtenursen der Hercegovina - Anthropogeographic Studies (Livestock Movements in Herzegovina - Anthropogeographic Study) (Пецељ, 2009). His work Herzegovina - an anthropogeographic study, with which the atlas goes, was published in the Serbian ethnographic collection of works of the Serbian Royal Academy of Sciences, 1909. After the Balkan Wars in 1912, he published a geographic - anthropogeographic study of New Serbia, with a map of the newly liberated regions (Дедијер, 1913). The name "New Serbia" was not very appropriate for these areas, because Serbia waged those wars for the liberation of Old Serbia and not for the creation of "New Serbia". S. Terzić gave an interesting observation that "a kind of cognitive and terminological path from Serbia, through Old Serbia to New Serbia, illustrates not only the degree of knowledge about Old Serbia, but also a certain historical and psychological picture of this historically central part of the Serbian political and cultural space. He also points to the discontinuity in historical consciousness and in the historical-geographical knowledge of the Serbian environment in the $19^{\text {th }}$ and early $20^{\text {th }}$ century (Terzić, 1997). During World War I, Dedier was in France and Switzerland, where he worked in the Ministry of the Army on creation of a geographical map of Yugoslav countries. The map was printed at the (Geoǵr. Establishment) Kümmerly \& Frey, in Bern in 1919 or early 1920 (Geographical Yournal, vol. 1, № 5, 1920). A good general idea is the relief, which is colored with shades of green, gray and yellow. The international borders were presented according to the situation before the beginning of the First World War in 1914.

Vojislav S. Radovanović (Pavlica, 1894 - Skopje, 1957), on the occasion of the 25th anniversary of liberation, published a book Географске основе Јужне Србије (Geographic Basis of Southern Serbia), with a map attached (Radovanović, 1937). The names Old Serbia and Southern Serbia were gradually suppressed by 
the names Macedonia, after the Second World War, the Republic of Macedonia, now days Northern Macedonia. The name Stara Raška (Old Raška) was maintained after the war, but the former Turkish name Sandžak was also used.

\section{Conclusion}

The development of scientific geography and cartography in Serbia in $19^{\text {th }}$ and early $20^{\text {th }}$ century, it was mutually connected and conditioned. Because of this history of geography and history of cartography should be studied in the interconnectivity and interdependence. By the second half of the $19^{\text {th }}$ mapping are practiced by individuals, enthusiasts who were aware of the importance of maps for enlightenment and the awakening of national consciousness, but also for military purposes. In the second half of the nineteenth and early twentieth century development of geography and cartography in Serbia receives a strong upswing establishment of two institutions - the Geographic Department of General Staff (now the Military Geographical Institute) and the Institute of Geography at the Big School (today's Faculty of Geography, University of Belgrade). Along with developing the specialized Library and collectibles, interact with market of old maps. In recent times, the history of cartography is becoming increasingly common theme in publications from the fields of history, geography, cartography and librarianship. Historical cartography gradually differentiated as a scientific discipline that studies ancient maps not only as historical sources and documents of his time, but also as artifacts in the historical and geographical context, which is a graphical language once strongly influenced the changing history

Acknowledgment: The work is the result of work on project 176017 funded by the Ministry of Education, Science and Technological Development of the Republic of Serbia.

\section{References}

АЛЕКСИЋ, А. (1876). Морава, њено садашње стање и могућност пловидбе. Гласник Српског ученог друштва, св. XI, други одељак, Београд.

АЛЕКСИЋ, А. (1882). Мачванска блатишта. Годищъиияа Николе Чупића. Београд. АЛЕКСИЋ, А. (1883). Грађа за картографију и географију Србије. Годишњииза Николе Чупића, књ. В, Београд, стр. 260-262.

АЛЕКСИЋ, А. (1865-66). План околине Београда 1:50.000. Београд.

АЛЕКСИЋ, А. (1891). Мачва са нарочитим погледом на поплавне прилике. Гласник Српског ученог друштва, св. LXXII, Београд. 
BAN, M. (1885). Solution de la question d'orient. Par le Europe ou par la Porte? Avec une carte. Belgrade. Imprimerie d'etat.

БЕШЛИЋ, J. (1884. и 1890). Карта Краљевине Србије 1:1.500.000. Београд.

БЕШЛИЋ, J. (1890). Карта Србије и Балканског полуострва, 1:300.000.

БУГАРСКИ, J. (1845). Карта Кғажевства Србије, 1:345.000. Београд.

ЦВИЈИЋ, J. (1889а). Ка познавању крша источне Србије. Београд, 1889.

ЦВИЈИЋ, J. (1889b). Карта Србије. Размер 1:75.000. Издаје Географско одељење српског Ђенералштаба, „Коло“ бр. 19-20. У књ. Јосип Симоновић (1896). Београд: Први топографски премер Краљевине Србије. Издање уредништва „Ратника“.

ЦВИЈИЋ, J. (1897, 1898, 1911). Карта Србије и Црне Горе, 1:750.000. Беч.

ЦВИЈИЋ, J. (1906). Основе за географију и геологију Македоније и Старе Србије, I -II. Државна штампарија Краљевине Србије. Београд.

ЦВИЈИТ, J. (1911). Основе за географију и геологију Македоније и Старе Србије, III, Београд.

CVIJIĆ, J. (1918). La péninsule balkanique. Géographie humaine. Paris, A. Colin. 1918. Српски превод: Балканско полуострво. Основе антропогеографије. Београд, 1966.

ЦВИЈИЋ, J. (1989). Принципи и методе за израду етнографске карте Балканског полуострва. Говори и чланци. Сабрана дела. Београд, 1989.

ЦВИЈИЋ, J. (1895). Специјална карта Србије, 1:75.000. Преглед географске литературе о Балканском полуострву за 1894. годину. Свеска II, Београд, 1895.

ЦВИЈИЋ, J. (1913). Распоред балканских народа - објашњење етнографске карте. Гласник Српског географског друштва. (превод претходно објављеног рада у часопису Petermans Mitteilungen). Београд, стр. 234-265.

CVIJIĆ, J. (1919). Frontiére septentrionale des Yougoslaves (avec trois cartes en couleurs hors texte). Paris.

ДАВИДОВИЋ, Д. (1821). Земље у којима пребивају Срби. Беч: Новине Српске. (Davidović, D. Countries in which Serbs reside. Novine Srpske, Vienna,1821)

ДЕДИЈЕР, Ј. (1913). Нова Србија. Српска књижевна задруга. Београд.

ДРАГАШЕВИЋ, J. (1858). Хомоље. Гласник Српског ученог друштва, св. IX. Beograd.

ДРАГАШЕВИЋ, J. (1873). Принос за географију Србије. Гласник Српског ученог друштва, XXXVI, 1, Београд.

ДРАГАШЕВИЋ, J. (1877). Археологијско-географијска истраживања. Гласник Српског ученог друштва, XLV, str. 1-128.

DRAGAŠEVIĆ, J. (1885). Carte etnographique de la presque'ile des Balkans dressee d'apres les documents historique et philologiques, Beograd.

ДРИНОВ, М. (1971). Ізбрани съчинения, том I. София. Наука и изкуство. 
ДУЧИЋ, Н. (1874). Црна Гора. Гласник Српског ученог друштва XV/1874, стр. 1-121. Београд, Државна штампарија.

ЂОРЂЕВИЋ, J. (1861). Радња Благовештенског сабора народа србског у Сремским Карловцима 1861. (издање аутора).

ЂОРЂЕВИЋ, J. (1861). Карта Бачке, Срема и Баната, 1:595.000, Нови Сад.

ГАВРИЛОВИЋ, J. (1994). Речник географијско-статистичниј Србије. Текст из 1846. приредио М. Радевић. “Култура”, Београд.

Географско одељење Главног Генералштаба, (1893). Генерална карта Краљевине Србије 1:200.000. Београд.

Географско одељење Главног Генералштаба, (1893). Генерална карта Краљевине Србије 1:75.000, на 94 листа. Београд.

GOPČEVIĆ, S. (1889a). Ethnographische Karte Alt-Serbien und Makedonien / von Spiridon

Gopčević, 1:300.000. In: Makedonien und Alt-Serbien. Wien: Verlag von L.W. Seidel \& Sohn, 1889.

Спиридон Гопчевић: Етнографска карта Старе Србије и Македоније, 1:300.000. Београд: Књижевни фонд Илије М. Коларца, 1890.

GOPČEVIĆ, S. (1889b). Etnographische karte von Makedonien und Alt-Serbien, [1 : 750.000]. (nulmeridian: Fero, mehrfarb. 49x49 cm). Petermanns Mitteilungen, 35. band, Gotha, p. 57-68.

HAARDT, V. HARTHENTURN (1901). Die Kartographie der Balkan-Halbinsel im XIX. Jahr-hundert. Mitteilungen des k.u.k. Militar-Geographischen Institutes. XXI. Band. 1901., str. 136-300, XXXII, Вd. 1902., str. 155-489. Wien 1902-1903. Види приказ у Прегледу географске литературе о Балканском полуострву В, уредио Ј. Цвијић, Београд, 1908, с. 6-20.

ИЛИЋ, Н. МИХАИЛО (1875). Моравска клисура међу Овчаром и Кабларом. Гласник Сриског ученог друштва, XLII, Београд 1875, 204.

ИВАНОВИЋ, Љ. (1869). Општа географска карта Србије 1:500.000. Београд.

ИВИЋ, П. (1922-а). Грађа за српску историјску географију. Гласник географског друштва. Београд, св. 7 и 8, стр. 197-207.

ИВИЋ, П. (1922-б). Грађа за историјску географију српске цркве. Гласник Географског друштва. Београд, св. 7 и 8, стр. 207-218.

ЈОВАНОВИЋ (капетан) (1869). Карта Кнежевине Србије 1:500.000. Београд.

КАРАЏИЋ, С. В. (1827). Географско-статистическо описаније Србије. “Данииа" II, Беч.

КАРАЏИЋ, С. В. (1969). Српска историја нашег времена. "Молит”, Београд.

КАРИЋ, В. (1887). Србија. Опис земље, народа и државе. Краљевска државна штампарија, Београд.

КАРИЋ, В. (1890). Карта српске земље и Балканског полуострва. 1:300.000. Београд. 
МАЧАJ, С. (1866). Грађа за топографију округа књажевачког и Карта Књажевачког округа по крокију од г. Јеврема Марковића, у размери 1:200.000. Гласник Српског ученог друштва, књ. II, св. ХІХ (старог реда). Београд, стр. 277$345+1$ карта.

МЕДОВИЋ, А. (1852). Окружје пожаревако. Гласник Друитва сриске словесности, св. IV, Београд.

МЕДОВИЋ, А. (1856). Карта окружја пожаревачког. Београд.

МИЛЕНКОВИЋ, J. (1850). Књажевство Србије. Карта 1:300.000 у 4 листа. Београд.

МИЛИЋЕВИЋ, Ђ. М. (1876). Кнежевина Србија. Београд.

МИЛОЈЕВИЋ, Ст., М. (1873). Историско-етнографско-географоска мапа Срба и српских (југословенских) земаља у Турској и Аустрији, 1:200.000. Изд. К. Атанасков-Шуменковић, Београд.

МИШКОВИЋ, J. (1872). Опис рудничког краја (са једном картом и таблицом). Гласник Српског ученог друштва, XXXIV, Београд, 1872, str. 178-335.

МИШКОВИЋ, J. (1881). Опис Књажевачког округа (са једном картом). Гласник Српског ученог друштва, књ. XLIX. Београд. Страна 53-124 + 1 карта.

МИШКОВИЋ, J. (1885). Топографски речник Јагодинског округа. Гласник Српског ученог друштва, књ. 61, Београд.

МИШКОВИЋ, J. (1900) Карта Косова поља, 1:150.000. Београд: Фото-литографска радионица Главног Ђенералштаба.

МОМИРОВИЋ, Д. (1839). Кратка историја и географија Србије. Сент Петерсбург.

ОБРАДОВИЋ, С. (1858). Описаније округа ужичког и Карта окружја ужичког 1:200.000. Гласник Друштва српске словесности. Св. Х. Београд.

ПЧЕЛАР, И. (1857). Карта окружја крајинског, Београд, 1856. Окружје крајинско, Гласник Друитва српске словесности, св. ІХ. Београд, 1857.

РАДОВАНОВИЋ, В. (1937). Географске основе Јужне Србије. Споменица двадесетпетогодишњице ослобођења Јужне Србије 1912-1937. Скопље, 1937.

СОЛАРИЋ, П. (1804). Ново гражданско землеописаније, прво на језику србском, са Землеописником од XXXVII листова. Венеција, 1804.

СТАЈИЋ, М. (1895). Карта Краљевине Србије 1:800.000. Београд.

СТОЈАНОВИЋ, Љ. (1922). Црна Гора и Бока Которска, СК3, 161, коло XXIV, Beograd.

ШРЕПАЛОВИЋ, К. П. (1895). Карта Краљевине Србије, 1:800.000. Београд.

ВЕСЕЛИНОВИЋ, М. (1886). Етнографска карта српских земаља. „Српство“ бр. 9, Београд.

ВУЈИЋ, J. (1999). Путешествије по Сербији. Лио. Горњи Милановац.

ЖЕГЛИГОВИЋ,Д. (1885). Етнографска карта Балканског полуострва [1:3.000.000], Београд. 


\section{Literature}

АНЪЕЛИЋ, М. (1990). Војна картографија и њен утицај на развој географских наука, Машинопис предавања одржаног у СГД, Београд.

БАКРАЧ,С.,РАДОЈЧИЋ,С.,СЕКУЛОВИЋ,Д. (2016).140годинаВојногеографског института - друштвено-политичке, војне и професионалне околности постојања. Војно дело, 7/2016. Београд, стр. 393-411.

БАКРАЧ, С., РАДОЈЧИЋ, С., ЂОРЪЕВИЋ, Д. (2015). Географско одељење у Првом светском рату. У: Први светски рат, Србија, Балкан и велике силе. Историјски институт, Београд. стр. 255-265.

БОЈОВИЋ Н. (уредник) (1997). Геокарта - 50 година успешног рада. Београд. „Геокарта“.

БОЙОВИЧ, Р. ( 2002). Карта ныне существующей Сербии Александра Григорьевича Розалион-Сошальского 1831. года. Харьковский исторический альманах, св. 1, Харьков, 22-27.

БОШКОВИЋ, С. (1930). Геодетски и картографски радови Војног географског института 1878-1930. Географоки и и етнографски преглед, Београд, 1-14.

ЦАРЕВИЋ, И. (2015). Допринос Јована Жујовића познавању геолошке грађе шире околине општине Књажевац. У: Стојановић В. и др. О Кюажевачком крају у научним радовима Јована Жујовића. Народна библиотека „Његош“, Књажевац, стр. 49-56.

ЋИРКОВИЋ, С. (1991). Сведочење карте. У: Срејовић Д. (уредник). Србија и суседне земље на старим географским картама. Галерија САНУ, 70. Београд, 11-18.

ЋУРЧИЋ, Л. (1976). Захарије Орфелин и српска књига, „Библиотекар“, Друштво библиотекара Србије, 28, 3/4 (1976), стр. 393-428.

DEMETER, G. and CSAPLÁR-DEGOVICS, K. and BOTTLIK, Z. (2015). Ethnic Mapping on the Balkans (1840-1925): a Brief Comparative Summary of Concepts and Methods of Visualization. In: (Re)Discovering the Sources of Bulgarian and Hungarian History. Institute of History, Bulgarian Academy of Sciences, Sofia; Budapest, pp. 65-100.

ДЕНИЋ,Ч. (1996). Погледи на дело Јована Рајића. Зборник Матице српске за историју, 1996, бр. 54, с. 1-47.

ДУКИЋ, Д. (1985). Улога Географског завода у развитку науке и наставе у Србији у протеклих 90 година. Посебна издања, књ. 3, Одсека за географију и просторно планирање ПМФ, Београд. стр. 8.

ДУКИЋ, Д. (1989). Развитак географских наука у САНУ (1886-1994), САНУ, Стогодишњица САНУ 1886-1986. Књ. II, Београд.

ГРБИЋ, Б., ЈОРДАНОВИЋ, Б. (2018). Преглед наставе на Лицеју, Великој школи и Универзитету 1838-1914. Универзитет у Београду. 
ГРЧИЋ, М. (1996). Елементи политичке географије и погледи на геополитичке проблеме Балкана у делима Јована Цвијића. Гласник - Herald, Географско друштво Републике Српске бр.1. стр. 67-77. Бања Лука.

ГРЧИЋ, М. (2001). Геополитичка картографија. У: Савремене тенденције у картографији. Зборник радова са научног скупа. Географски факултет, Београд, стр. 90-101.

ГРЧИЋ, М. (2005): Развој научне географије у Србији и осталим српским земљама. У: Стаменковић С. и Грчић М. (ред.): Србија и савремени процеси у Европи и свету. Географски факултет БУ, Београд, стр. 7-17.

GRČIĆ, M., GRČIĆ, LJ. SIBINOVIĆ, M. (218). The geographical position of the town of Rasa based on Porphyrogenitus and medieval maps. Acta Geographica Slovenica. 58-1. Ljubljana. 39-47.

HARLEY, J. B. (1990). Introduction: text and contexts in interpretation of early maps. Chicago.

ИЛИЈИЋ, Б. (2015). Timacum Minus - два света. Завичајни музеј Књажевац, Књажевац, 88 стр.

ЈОВАНОВИЋ, В. (2012). Марсиљијева картографија Дунава од Бездана до Београда. У: Костић, Ђ. (уредник). Дунав од Бездана до Београда. Балканолошки институт. Београд. с. 203-214.

ЈОВОВИЋ, Б., ШУљАГИЋ, Р. (2016). Јован Драгашевић. „Одбрана“, Београд, с. 384.

JOVANOVIĆ, P. (1958). Geografija u Srbiji. Enciklopedija Jugoslavije, T. III, Leksikografski zavod FNRJ, Zagreb, c. 439.

LAZAR - VUKOTIĆ, M., DANILOVIĆ- HRISTIĆ, M. (2015). The Growin and development of Belgrade in the period from 1815 to 1910, Collection of papers of the Faculty of Philosophy XLV (3), 2015. str. 61-80.

ЛУТОВАЦ, М. (1966). Значај рада Вука Караџића за нашу географију. Вуков зборник, Посебна издања САНУ, књ. CD, Београд.

МИХАИЛОВИЋ, Р. (2016). Културно памћење тршћанских Срба. Докторска дисертација. Универзитет „Џон Несбит“. Београд. 2016.

МИЛОЈЕВИЋ, Б. Ж. (1927), Јован Цвијић. Цвијићева књига. Српска књижевна задруга, коло XXX, бр. 201, Београд.

МИЛОШЕВИЋ, П. (2000). Милош Ст. Милојевић - Сажети животопис. У књ. Милојевић М.: Одломци историје Срба и српских - југословенских земаља у Турској и Аустрији, І. свеска. Београд, 1872. Репринт издање 2000.

МИШИЋ, С. (2003). Рајићева Историја и историјска географија, Зборник Матище српске за историју, 2003, бр. 67-68, стр. 23-36.

MITROVIĆ, M. et al. (2009). Cultura Serba a Trieste. Lecce: Argo, 2009.

ПАВЛОВИЋ, Б. (2007). Поруке прошлих времена. Историја и традиција филантропије у Србији у XIX и XX веку. Балкански фонд за локалне иницијативе. Београд. 
ПЕЦЕЉ, М. (2009). Јевто Дедијер - живот и дело. Београд - Бања Лука.

ПЕЦЕЉ, М., СТАНКОВИЋ, С. (2019). Географи у великом рату. Универзитет у Београду - Географски факултет, Београд.

ПЕТРОВИЋ, Д. (1980). Прилог историјском развоју српске географије (18041829.). Гласник Сриског геограбрског друштва, св. 60, бр. 1, Београд.

ПЕТРОВИЋ, Д. (1997). Српска географија ХІХ века. Флогистон - часопис за историју науке, бр. 5, Београд.

ПЕТРОВИЋ, Д., ЖИВКОВИЋ, Д. (1985). Цвијићев допринос развоју тематске картографије. Зборник радова, св. 32. ПМФ - Институт за географију, Београд. 121-132.

ПОПОВИЋ, Д. (1954). Београд за време Карађорђева устанка. У: Географски лик Србије у доба Првог устанка, Посебна издања СГД, св. 32, Београд, 1954.

РАДОЈЧИЋ, Н. (1924). Однос измећу географије и српске историографије. Зборник радова посвећен Јовану Цвијићу. Београд.

РАДОЈЧИЋ, Н. (1927). Географско знање о Србији почетком 19. века. Посебна издања Географског друштва, св. 2, Београд, 1927.

RADOJČIĆ, N. (1925). Rankeova nova koncepcija srpske istorije. Razprave Znanstvenog društva za humanističke vede, II (1925), 23, 37-38.

РАДОЈЧИЋ, С. (1997). Почетак нововековне српске картографије. Гласник Српског географрског друштва, св. LXXVII - 2, стр. 61-65.

РАДОЈЧИЋ, С. (1998). Стеван П. Бошковић (1868-1957), у: „Живот и дело сриских научника", књ. 3, Српска академија наука и уметности, стр. 221-268, Београд.

RADOJČIĆ, S. (1998). Academician and geodetic general Stevan P. Boskovic, the head of Military Geographic Institute in Belgrade. Geonauka, vol. 2, № 1 (2014), Beograd, 9-13.

РАДОЈЧИЋ, С., СРДИЋ, 3. (2014). Астрономски и геодетски радови бечког Војногеографског института у Кнежевини Србији 1874. године. Зборник радова конференције „Развој астрономије код Срба VII“ одржане 2012. (уредник М. Димитријевић). Астрономско друштво „Руђер Бошковић“, бр. 13, 2014, Београд, стр. 411-420.

RADOJČIĆ, S., BAKRAČ, S., AMOVIĆ, M. (2015). Jovan Cvijić and the headquarters map of the Kingdom of Serbia 1:75.000. International conference 150th anniversary of Jovan Cvijic's birth. Geographical Institute "Jovan Cvijić" of SANU. Belgrade. 753-766.

РАДОШЕВИЋ, Н. (1974). Преглед историје картографије југословенских земаља. У: Петерца М., Радошевић Н., Милисављевић С., Рацетин Ф. Картографија. Војногеографски институт, Београд.

РАДОШЕВИЋ, Н. (1976) Захарије Стефановић Орфелин. Гласник Српског географског друштва, 2/1976. s. 97-111. 
РАКИЋЕВИЋ, Т. (1995). Географија Срба у 18. веку и првој половини 19. века. Зборник радова научног скупа: Природне и математичке науке у Срба у 18. и у првој половини 19. века. САНУ, огранак у Новом Саду. Стр. 99-108.

РАКИЋЕВИЋ, Т. (1996). Заснивање географије као науке у обновљеној Србији. У: Пола века науке и технике у обновљеној Србији 1804-1854. Реферати са научног скупа одржаног 25. и 26. октобра 1995. Крагујевац, с. 444-454.

РИСТИЋ, К. (1993). Стање и проблеми у настави регионалне географије. Зборник радова Географског фракултета ПМФ, св. 42, Београд.

РИСТИЋ, М. (1948). О почетку наше географске наставе. Гласник СГД, XXVIII-1, Београд.

РИСТИЋ, М. (1957). Први уџбеник географије у београдској Великој школи Карађорђева доба. Гласник СГД, св. XXVIII, бр. 2, Београд.

САВИЋ, Р. (уредник), (1987). Геодетска делатност у Србији. Републ. геодетска управа, Београд.

СИБИНОВИЋ, М. (2011). Грађа за топографију Књажевачког округа Стевана Мачаја. У: Стојадиновић, В. (уред.): „Грађа за топографију округа Кюажевачког“ Стевана Мачаја. Народна библиотека „Његош“, Књажевац, стр. 96-120.

СИНДИК, И. (1930). Физиогеографски елементи на старим картама југословенских земаља. Гласник Српског географског друитва, бр. 16. с. 122-135.

СРЕТЕНОВИЋ, Љ. (1985). Удео илустрација у Цвијићевим радовима. Развитак и примена географске науке у Србији за протеклих девет деценија. ПМФ, Одсек за географију и просторно планирање, Београд.

СТАНКОВИЋ, С. (2012а). Стогодишњица Српског географског друштва (1910-2010). У: Станковић, С. (уредник) Споменииа о стогодищњищи Српског географског друштва. Посебна издања Српског географског друштва, књ. 72, Београд, 3-66.

СТАНКОВИЋ, С. (2012б). Страни научници о Јовану Цвијићу. Часопис за културну историју Јадра, Призор, бр. 11, Центар за културу „Вук Караџић“, Лозница.

СТАНКОВИЋ, С. (2019). Јован Цвијић 1927. Географски факултет, Универзитет у Београду, 2019.

СТЕФАНОВИЋ, О. (2003). Српска картографија 19. века. Гласник Народне библиотеке Србије, 1/2003. с. 99-106.

ШЕШУМ, С. У. (2015). Србија и Стара Србија (1804-1839). Докторскадисертација. Универзитет у Београду - Филозофски факултет. Београд.

ШКАЛАМЕРА, Ж. (1991). Картографија Србије и југословенских земаља од XVI до XIX века. У: Срејовић Д. (уредник): Србија и суседне земље на старим географским картама. Галерија САНУ, 70. Београд стр. 55-166.

ТЕРЗИТ, С. (1997). Стара Србија - настанак имена и знаға о юој до 1912. Историјски часопис, књ. XLII-XLIII (1995-1996). Beograd. Str. 91-110. 
ТЕРЗИЋ, С. (2008). Историјско-географске представе о Старој Србији у Европи и међу Србима. «Наша прошлост», бр. 9. Народни музеј и Историјски архив. Краљево. стр. 9-28.

TOMIĆ, V. (2018). The Viennese view on Belgrade. Belgrade in the works of Viennese engravers between the $17^{\text {th }}$ and the $19^{\text {th }}$ century from the Belgrade city museum collection, In: Belgrade 1521-1867., Collection of Works, The Institut of History, Belgrade, ed. D. Amedovski, p. 453-478.

ТРГОВЧЕВИЋ, Љ. (1986). Научници Србије и стварање Југославије 1914-1920. Народна књига и СК3, Београд. 359 с.

ВАСОВИЋ, М. (1987). Вук Караџић и наша географија. Гласник Сриског географског друштва, св. LXVII-2, Београд.

ВЕМИЋ, М. ( 2005). Цвијић и картографија. «Глобус», бр. 30, СГД, Београд. с. 159-170.

ВЕМИЋ, М. (2007). Картографија Србије у 20. веку. Зборник радова бр. 57. ГИ «Јован Цвијић» САНУ. Београд, с. 407-415.

ВУКАНОВИЋ, Т. (1947). Вуков рад на проучавању наше земље и народа. Гласник Географског друштва, св. 27, Београд. с. 37-48.

WILKINSON, H. R. (1951). Maps and Politics: a Review of the Ethnographic Cartography of Macedonia. Liverpool: Liverpool University Press. XVI+366 pp.

ЖИВКОВИЋ, Д. (2012). Српска картографија од инжењерске до дигиталне. Гласник Српског географрског друштва, бр. 3/2012. Београд, 1-10.

ЖИВКОВИЋ, Д. (2017). Картографија - од цртежа до интегративне науке. У: Јојић Д. (уредник): Зборник радова поводом обиљежавања 20 година рада Природно математичког факултета Универзитета у Бањалуци. 299-302.

YOSMAOĞLU, I. (2013). Blood Ties: Religion, Violence and the Politics of Nationhood in Ottoman Macedonia, 1878-1908. Cornell University Press, 2013. p. 336. 